\title{
Caracterización de la leche y clasificación de calidad mediante análisis Cluster en sistemas de doble propósito
}

\section{Characterization of milk and quality classification by Cluster analysis in dual purpose systems}

\author{
J osé Manuel J uárez-Barrientosa, Pablo Díaz-Riveraa, J esús Rodríguez-Mirandab, \\ Cecilia E. Martínez-Sánchezb, Betsabé Hernández-Santosb, Emmanuel Ramírez-Riveraa, \\ Juan G. Torruco-Ucob, Erasmo Herman-Larab
}

\begin{abstract}
RESUMEN
Debido a la falta de información sobre la calidad de la leche y la heterogeneidad en los sistemas de doble propósito del trópico mexicano, la capacitación no se destina a los grupos que la requieren. Por lo tanto el objetivo de este estudio fue caracterizar la leche de estos sistemas, compararla con las normas de referencia y relacionarla con las prácticas de manejo. Además de proponer una metodología para identificar los grupos que requieren acciones de intervención. Se evaluó la composición fisicoquímica y microbiológica en 192 muestras de leche cruda en siete localidades. Se determinó el efecto de las prácticas de manejo sobre las características de la leche mediante análisis de varianza. Se aplicó un análisis cluster para agrupar las muestras con base en el contenido de grasa, sólidos no grasos, crioscopía y acidez titulable. El $65 \%$ de las muestras presentaron valores fuera de norma (sólidos, densidad y crioscopía, sugiriendo una adulteración por adición de agua). El uso de oxitocina, tipo de ordeño, raza y suplementación afectaron $(P<0.05)$ las características de la leche. Mediante el análisis cluster se identificaron cinco grupos de calidad. Los grupos de excelente y buena calidad presentaron valores dentro de las normas de referencia en todos los parámetros evaluados. Los grupos de deficiente, mala y muy mala calidad $(47 \%)$ presentaron valores elevados de crioscopía y bajo contenido de sólidos. Con la metodología propuesta se espera facilitar la intenvención enfocada a resolver problemas específicos, evitando el dispendio de recursos.
\end{abstract}

PALABRAS CLAVE: Análisis cluster, Calidad de la leche, Sistema de doble propósito.

\begin{abstract}
Due to lack information about the milk quality and heterogeneity in dual purpose systems in the Mexican tropics, training is not directed to groups where is required. Therefore, the aim of this study was to characterize the milk of these systems compared to the reference standards and to establish the relationship with management practices. Addition to proposing a methodology to identify groups and production units that require intervention actions. Physicochemical and microbiological composition of 192 raw milk samples from different production units in seven locations were evaluated. The effect of management practices on the characteristics of milk by analysis of variance was determined. A cluster analysis was applied for grouping the samples based on the fat content, nonfat solids, titratable acidity and cryoscopy. A $65 \%$ of the samples showed values out of specification (solid, density and cryoscopy, suggesting an adulterated milk with water). The use of oxytocin, milking type, breed, production system and supplementation affected $(P<0.05)$ the yield and characteristics of the milk. Through Cluster analysis five quality groups were identified. Groups of excellent and good quality showed values within or close to the reference standards in all parameters evaluated. The groups of poor, bad and very bad quality (47 \%) had high values of cryoscopy and low solids content. Through the proposed methodology is expected to facilitate the directed intervention from government and private agencies to solve the problems identified, avoiding the waste of supports.
\end{abstract}

KEY WORDS: Cluster analysis, Milk quality, Dual purpose system.

Recibido el 27 de marzo de 2015. Aceptado el 24 de agosto de 2015.

a Colegio de Postgraduados, Campus Veracruz. Veracruz, Veracruz, México.

b Instituto Tecnológico de Tuxtepec. Av. Dr. Víctor Bravo A. s/n. 68300 Tuxtepec, Oaxaca, México. Tel: (287) 875 1044; erasmo_hl@hotmail.com. Correspondencia al último autor. 


\section{INTRODUCCIÓN}

El sistema de doble propósito (DP) en el trópico mexicano aporta más del $18 \%$ de la producción nacional de leche(1) y se caracteriza por su heterogeneidad a nivel estructural, tecnológico y de manejo(2), ocasionando que existan diferencias muy marcadas entre unidades de producción de leche, incluso en una misma zona(3) causando variabilidad en las características de la leche ${ }^{(4)}$. Actualmente en el Distrito de Desarrollo Rural 008, Veracruz, México (DDR 008); conformado por los municipios de Cosamaloapan, Chacaltianguis, Otatitlán, Tlacojalpan, Tuxtilla, Tres Valles, Carlos A. Carrillo, Amatitlán, Ixtamatlahuacan, Tlacotalpan, Tierra Blanca y Acula(5), no existe información sobre las características de la leche producida y su calidad con respecto a las normas nacionales e internacionales. Por lo tanto, los programas de capacitación son destinados en forma indiscriminada, sin tomar en cuenta las necesidades específicas de los productores.

Por otro lado, los estudios sobre las características de la leche y su relación con las prácticas de manejo en distintas partes del mundo(6-8) plantean un tratamiento estadístico univariado que no permite la identificación de grupos problemáticos, dificultando la implementación de estrategias. Sin embargo, existen técnicas estadísticas multivariadas como el análisis cluster, que permite clasificar los datos en grupos homogéneos y diferenciarlos con base en la heterogeneidad entre grupos(9). Esta clasificación genera información que facilita la identificación de grupos específicos y la orientación de medidas preventivas o correctivas con el objetivo de mejorar la calidad de la leche producida. Con base en lo anterior, los objetivos de la presente investigación fueron: a) conocer las características fisicoquímicas y microbiológicas de la leche producida en siete localidades del DDR 008, compararla con las normas nacionales e internacionales, y establecer su relación con las prácticas de manejo y b) crear una clasificación de la leche con base en la calidad que permita identificar los grupos que requieren apoyo.

\section{INTRODUCTION}

The dual purpose system (DP) in the Mexican tropic produce more than $18 \%$ of the national milk production(1) and is characterized by its heterogeneity at the structural, technological and management level(2), resulting in strong differences among milk production units, even in the same area(3) causing variability in the milk characteristics (4). Currently, in the district's Rural Development 008, Veracruz, Mexico (DDR 008); formed by the municipalities of Cosamaloapan, Chacaltianguis, Otatitlán, Tlacojalpan, Tuxtilla, Tres Valles, Carlos A. Carrillo, Amatitlán, Ixtamatlahuacan, Tlacotalpan, Tierra Blanca and Acula(5), there is no information on the characteristics and quality of the milk produced compared to national and international standards. Therefore, capacitation programs are indiscriminately aimed, without taking into account the specific needs of producers.

On the other hand, studies on the milk characteristics and its relationship with management in different parts of the world(6-8) propose a univariate statistical treatment which does not allow the identification of problematic groups, hampering the implementation of strategies. However, there are multivariate statistical techniques such as the cluster analysis, which allows to classify data in homogeneous groups and differentiate them based on heterogeneity among groups(9). This classification generates information that facilitates the identification of specific groups and the orientation of preventive or corrective measures with the aim of improving the milk quality. Based on this, the objectives of this research were: a) Knowing the characteristics of physicochemical and microbiological milk produced in seven towns of the DDR 008, compared with national and international standards and their relationship with management practices and b) Create a milk classification based on the quality that allows identifying the groups that require support. 


\section{MATERIAL Y MÉTODOS}

Muestreo de leche

Se realizó un muestreo estratificado con asignación proporcional, tomando en cuenta el número de unidades de producción (UP) en cada municipio, y como variable de referencia el número de vientres por UP. Se tomaron 192 muestras de leche cruda de distintas UP de las localidades de: Tierra Blanca (114), Tres Valles (6), Carlos A. Carrillo (18), Laguna de lagarto (30), Cosamaloapan (6), Acula (12) e Ixmatlahuacan (12), pertenecientes al DDR 008, Cd. Alemán, Veracruz, México, que en conjunto aportan el $90.5 \%$ de la producción de leche en el distrito(10). Las muestras se tomaron de los tanques de acopio en un tiempo de $60 \pm 10$ min, posteriores al ordeño y se trasladaron en una hielera de poliestireno a una temperatura de $4 \pm 1{ }^{\circ} \mathrm{C}$ para su análisis en un lapso de tiempo de $3 \pm 1 \mathrm{~h}(11)$.

\section{Características fisicoquímicas}

Se evaluó el contenido (en g/L) de grasa (GR), proteína (PR), lactosa (LA), sólidos no grasos (SNG), además de la densidad (DE en $\mathrm{g} / \mathrm{ml}$ ) y crioscopía (CR en ${ }^{\circ} \mathrm{C}$ ) usando un analizador por ultrasonido Lactoscan S (Milkotronic Ltd., 4 Narodni Buditeli Str. 8900 Nova Zagora Bulgaria) previamente calibrado y validado, presentando un error promedio de $0.025 \%$ con las determinaciones realizadas de acuerdo con la $\operatorname{AOAC}(12)$.

Grupos indicadores de contaminación

Se tomaron $10 \mathrm{ml}$ de leche en $90 \mathrm{ml}$ de una solución estéril de peptona y se colocaron en un homogeneizador Stomacher ${ }^{\circledR}$ modelo 400 Circulator (Seward Limited, UK) por un minuto a $265 \mathrm{rpm}$. Se prepararon diluciones $10^{-1}, 10^{-2}$ y 10-3. Se evaluó el conteo total bacteriano (CTB) y conteo de coliformes totales (CCT)(12). Los valores obtenidos en unidades formadoras de colonia por mililitro ( $\mathrm{ufc} / \mathrm{ml}$ ) se transformaron a escala de $\log _{10}(13)$ para ser usados en análisis posteriores. Se midió la acidez titulable (AT)

\section{MATERIAL AND METHODS}

Milk sampling

It was a stratified sampling with proportional allocation, taking into account the number of production units (PU) in each municipality, and as reference variable the number of cows by PU. Samples ( $n=198$ ) of raw milk from different PU locations were taken: Tierra Blanca (114), Tres Valles (6), Carlos A. Carrillo (18), Laguna de lagarto (30), Cosamaloapan (6), Acula (12) and Ixmatlahuacan (12), belonging to the DDR 008 Cd. Alemán, Veracruz, México, which together provide $90.5 \%$ of the milk production in the district(10). Samples were taken from the storage tanks in $60 \pm 10$ min, after milking and moved in a cooler box at $4 \pm 1{ }^{\circ} \mathrm{C}$ for analysis in a time span of $3 \pm 1 \mathrm{~h}(11)$.

Physicochemical characteristics

Fat content (FT), protein (PR), lactose (LA) and nonfat solids (NFS), were evaluated. Additionally, density (DE) and cryoscopy (CR) by ultrasound using a scanner Lactoscan S (Milkotronic Ltd, 4 Narodni Buditeli str. 8900 Nova Zagora, Bulgaria) previously calibrated and validated, presenting an average error of $0.025 \%$ with determinations made in accordance with the AOAC(12).

Contamination indicators groups

A mixture of milk ( $10 \mathrm{~mL}$ ) and $90 \mathrm{~mL}$ of sterile peptone solution was placed in a homogenizer (Stomacher ${ }^{\circledR}$, model 400 circulator Seward Limited, UK) for a minute at $265 \mathrm{rpm}$. Dilutions of $10^{-1}, 10^{-2}$ and $10^{-3}$ were prepared to assess the total bacterial count (TBC) and total coliform counts $(\mathrm{TCC})^{(12)}$. Values obtained in colony forming units per milliliter ( $\mathrm{cfu} / \mathrm{mL}$ ) were transformed into $\log _{10}$ scale(13) to be used for further analysis. Titratable acidity (TA) was reported as the average value in grams of lactic acid per liter of milk $(\mathrm{g} / \mathrm{L})(14)$.

\section{Management practices}

In each PU a questionnaire was applied to obtain information on the production system (PS), 
reportada como el valor promedio en gramos de ácido láctico por litro de leche $(\mathrm{g} / \mathrm{L})^{(14)}$.

Prácticas de manejo

En cada UP se aplicó un cuestionario para obtener información sobre el sistema de producción (SP), raza predominante, tipo de ordeño, prácticas de suplementación, uso de oxitocina y rendimiento ( $L \cdot$ vaca- $\left.^{-1}\right)$.

\section{Análisis estadístico}

Se realizó un análisis univariado para describir las prácticas de manejo y características de la leche. Se efectuaron análisis de varianza (ANDEVA) a una y dos vías para determinar el efecto de SP, raza, tipo de ordeño, suplementación y uso de oxitocina sobre el rendimiento y las características de la leche. Se aplicó un análisis cluster para agrupar las leches con base en su calidad a partir de las variables GR, SNG, CR y AT, estableciendo como referencia la distancia eucladiana, utilizando el algoritmo de ligamiento completo. La diferencia entre los grupos identificados se estableció mediante la prueba de la mínima diferencia significativa del predominantly breed, type of milking, supplementation practices, use of oxytocin and milk yield $\left(\mathrm{L} \cdot \mathrm{COW}^{-1}\right)$.

Statistical analysis

A univariate analysis was performed to describe management practices and milk characteristics. Two-way analysis of variance (ANOVA) were applied to determine effects of PS, breed, type of milking, supplementation and use of oxytocin on milk characteristics and milk yield. Cluster analysis served to group milk based on their quality from FT, NFS, CR and TA variables, establishing as reference the Euclidian distance, using the full linkage algorithm. The test of least significant difference of the Fisher procedure established the difference among the identified groups to a significance level of $5 \%$. Statistics statistical package version 7.0 was used.

\section{RESULTS}

Physicochemical characteristics

The contrast of results with standard references it shows in Table 1. The FT content showed a

Cuadro 1. Calidad fisicoquímica, grupos indicadores de contaminación y comparación con las normas nacionales e internacionales

Table 1. Physicochemical quality, spoilage indicators groups of milk and comparison with national and international standards

\begin{tabular}{|c|c|c|c|c|}
\hline \multirow[b]{2}{*}{ Variable } & \multirow[b]{2}{*}{ Mean value } & \multirow{2}{*}{$\frac{\text { Range }}{\text { Minimum - maximum }}$} & \multicolumn{2}{|c|}{ Reference } \\
\hline & & & National & International \\
\hline$\overline{\text { Fat, } g / L}$ & $34.8 \pm 7.8$ & $14.2-51.4$ & 32 minimum (1) & $32-55(5)$ \\
\hline Density, g/L & $1027.45 \pm 0.90$ & $1025.2-1030.5$ & 1029 minimum (1) & $1032(5)$ \\
\hline Nonfat solids, g/L & $79.2 \pm 2.5$ & $73.4-87.0$ & 83 minimum (1) & $82-100(5)$ \\
\hline Protein, $g / L$ & $29.5 \pm 0.9$ & $27.3-32.2$ & 31 minimum (1) & $26-36(5)$ \\
\hline Lactose, g/L & $41.9 \pm 1.3$ & $38.8-45.0$ & $43-50(1)$ & $46-50(5)$ \\
\hline Cryoscopy, ${ }^{\circ} \mathrm{C}$ & $-0.490 \pm 0.02$ & $-0.538--0.451$ & $-0.530--0.560(1)$ & $-0.512--0.550(5)$ \\
\hline Titratable acidity, g/L & $1.32 \pm 0.17$ & $0.67-1.75$ & $1.3-1.6(1)$ & $1.4-1.8^{(5)}$ \\
\hline Bacterial count, cfu/mL & $1.1 \times 10^{4} \pm 0.9 \times 10^{4}$ & $6.5 \times 10^{2}-6.6 \times 10^{4}$ & $<1.0 \times 10^{5}(1)$ & $<1.0 \times 10^{5(2)}$ \\
\hline Total coliforms count, cfu/mL & $5.8 \times 10^{2} \pm 1.8 \times 10^{2}$ & $1.0 \times 10^{2}-2.4 \times 10^{4}$ & $<7.5 \times 10^{2}(3)$ & $<7.5 \times 10^{2}(4)$ \\
\hline
\end{tabular}

(1) NOM-155-SCFI-2012, (2)Calderón et al. (2006), (3)NMX-F-700-COFOCALEC-2004, (4)PMO, 1995, (5)Draaiyer et al. (2009). The results represent the average of three determinations \pm standard deviation. 
procedimiento de Fisher a un nivel de significancia del $5 \%$. Se usó el paquete estadístico Statistica versión 7.0.

\section{RESULTADOS}

Características fisicoquímicas

El contraste de los resultados con las normas de referencia se muestra en el Cuadro 1 . El contenido de GR presentó una alta variabilidad con un valor promedio de $34.8 \mathrm{~g} / \mathrm{L}$ que cumplió la norma nacional NOM-155-SCFI-2012(14) e internacional señalada por la FAO(15). Los valores promedio de PR (29.5 g/L), LA (41.9 g/L), SNG $(79.2 \mathrm{~g} / \mathrm{L}), \mathrm{CR}\left(-0.490^{\circ} \mathrm{C}\right)$ y DE $(1027.45$ $\mathrm{g} / \mathrm{L}$ ) no cumplieron con los intervalos mínimos de la norma NOM-155-SCFI-2012(14) y los establecidos por la $F A O(15)$, excepto la PR que sí cumplió con el mínimo promedio de la norma internacional.

Grupos indicadores de contaminación

En el Cuadro 1 se presentan los resultados de los conteos bacterianos, AT y la comparación con las normas de referencia. El CTB $(1.08 \mathrm{x}$ $\left.10^{4} \mathrm{ufc} / \mathrm{ml}\right)$ y CCT $\left(5.80 \times 10^{2} \mathrm{ufc} / \mathrm{ml}\right)$ cumplieron con los valores normativos. Sin embargo, se observó una amplia variabilidad en CCT, ubicándose el $28 \%$ de las muestras por encima de los estándares establecidos en la norma NOM-155-SCFI-2012(14). El valor promedio de AT cumplió con los valores establecidos por la norma NOM-155-SCFI$2012^{(14)}$ y la $\mathrm{FAO}(15)$, pero en el intervalo $(0.67$ - $1.75 \mathrm{~g} / \mathrm{L}$ ) se observó que el $2 \%$ de las muestras presentaron valores superiores a los establecidos por la norma mexicana.

Prácticas de manejo y relación con las características de la leche

Las cruzas presentes en las UP fueron: Suizo $x$ Cebú (61 \%), Holstein x Cebú (9.4\%), Cebú ( $7.8 \%$ ) y cruza no definida ( $22 \%$ ). El hato se manejó bajo un sistema de pastoreo (87.5 \%) y semi-estabulado ( $12.5 \%)$. El ordeño se realizó básicamente de forma manual (94\%) y con menor frecuencia de manera mecánica (6\%). high variability with an average of $34.8 \mathrm{~g} / \mathrm{L}$, which accomplished the national standard NOM155-SCFI-2012(14-) and the international standard signed by $\mathrm{FAO}(15)$. The average values of PR (29.5 g/L), LA (41.9 g/L), NFS (79.2 g/L), CR $\left(-0.490^{\circ} \mathrm{C}\right)$ and DE $(1027.45 \mathrm{~g} / \mathrm{L})$ did not meet the minimum intervals of the standard NOM-155-SCFI-2012(14) and those established by $F A O(15)$, except the PR that met the minimum international standard average.

\section{Contamination indicators groups}

Table 1 presents the results of bacterial counts, $\mathrm{TA}$ and comparison with reference standards. The TBC $\left(1.08 \times 10^{4} \mathrm{cfu} / \mathrm{mL}\right)$ and TCC $(5.80 \times$ $10^{2} \mathrm{cfu} / \mathrm{mL}$ ) met with regulatory values. However, there was a wide variability in TCC, reaching $28 \%$ of the samples above the standards set out in the standard NOM-155SCFI-2012(14). The average value of TA complied with the values set by the standard NOM-155-SCFI-2012 (14) and FAO(15), but in the interval $(0.67$ to $1.75 \mathrm{~g} / \mathrm{L})$ it was observed that $2 \%$ of the samples had values above those established by Mexican standards.

Management practices and relationship with the characteristics of the milk

Breed crosses present in the PU were Swiss $x$ Zebu (61 \%), Holstein x Zebu (9.4\%), Zebu ( $7.8 \%)$ and crosses not defined (22\%). The herd was handled under a grazing system $(87.5 \%)$ and semi-stabled (12.5\%). Milking was carried out manually (94\%), and less frequently in a mechanical manner $(6 \%)$. In $20.5 \%$ of cases, cows receive balanced feed supplementation. The milk ejection was induced: without using oxytocin ( $47 \%)$, with partial use, only in hard milking cows (30\%) and application to the entire dairy herd $(23 \%)$. The milking herd averaged 34 cows, with an average yield of $4.95 \mathrm{~L} \cdot \mathrm{Cow}^{-1}$.

The results of the ANOVA (Tables 2 and 3) showed that in the UP where the Holstein $x$ Zebu crossing dominated, yield increased with a lower content of FT and PR in milk and CR 
José Manuel Juárez-Barrientos, et al. / Rev Mex Cienc Pecu 2016;7(4):525-537

Cuadro 2. Efecto de las prácticas de manejo sobre la calidad fisicoquímica de la leche y rendimiento productivo Table 2. Effect of management practices on the physicochemical milk quality and productive yield

\begin{tabular}{lrrrrrrr}
\hline & Fat $(\mathrm{g} / \mathrm{L})$ & Density $(\mathrm{g} / \mathrm{mL})$ & Nonfat solids $(\mathrm{g} / \mathrm{L})$ & Protein $(\mathrm{g} / \mathrm{L})$ & Lactose $(\mathrm{g} / \mathrm{L})$ & Crioscopy $\left({ }^{\circ} \mathrm{C}\right)$ & Yield $\left(\mathrm{L} \cdot \mathrm{COW}^{-1}\right)$ \\
\hline Breed: & & & & & & & \\
ZE & $3.85 \pm 1.16 \mathrm{~b}$ & $1027.18 \pm 0.81 \mathrm{a}$ & $7.84 \pm 0.13 \mathrm{ab}$ & $2.95 \pm 0.04 \mathrm{~b}$ & $4.16 \pm 0.07 \mathrm{ab}$ & $-0.494 \pm 0.01 \mathrm{ab}$ & $3.97 \pm 0.92 \mathrm{a}$ \\
$\mathrm{SZ}$ & $3.70 \pm 0.66 \mathrm{~b}$ & $1027.36 \pm 0.90 \mathrm{a}$ & $7.98 \pm 0.04 \mathrm{~b}$ & $2.96 \pm 0.09 \mathrm{~b}$ & $4.19 \pm 0.13 \mathrm{ab}$ & $-0.496 \pm 0.01 \mathrm{a}$ & $4.74 \pm 0.90 \mathrm{a}$ \\
UD & $3.20 \pm 0.66 \mathrm{~b}$ & $1027.96 \pm 0.90 \mathrm{a}$ & $8.03 \pm 0.24 \mathrm{~b}$ & $2.98 \pm 0.08 \mathrm{~b}$ & $4.25 \pm 0.13 \mathrm{~b}$ & $-0.500 \pm 0.02 \mathrm{a}$ & $5.14 \pm 1.04 \mathrm{a}$ \\
HZ & $2.30 \pm 0.70 \mathrm{a}$ & $1026.97 \pm 0.54 \mathrm{a}$ & $7.67 \pm 0.19 \mathrm{a}$ & $2.85 \pm 0.07 \mathrm{a}$ & $4.06 \pm 0.09 \mathrm{a}$ & $-0.471 \pm 0.01 \mathrm{~b}$ & $6.71 \pm 1.29 \mathrm{~b}$ \\
Milking type: & & & & & & \\
HAN $3.57 \pm 0.69 \mathrm{~b}$ & $1027.49 \pm 0.90 \mathrm{a}$ & $7.94 \pm 0.23 \mathrm{~b}$ & $2.95 \pm 0.08 \mathrm{~b}$ & $4.20 \pm 0.12 \mathrm{~b}$ & $-0.496 \pm 0.016 \mathrm{a}$ & $4.78 \pm 0.95 \mathrm{a}$ \\
MEC $2.05 \pm 0.60 \mathrm{a}$ & $1026.68 \pm 0.39 \mathrm{a}$ & $7.55 \pm 0.09 \mathrm{a}$ & $2.81 \pm 0.03 \mathrm{a}$ & $4.00 \pm 0.05 \mathrm{a}$ & $-0.461 \pm 0.007 \mathrm{~b}$ & $7.55 \pm 0.05 \mathrm{~b}$ \\
Oxytocin: & & & & & & \\
NO & $3.58 \pm 0.85 \mathrm{a}$ & $1027.50 \pm 0.94 \mathrm{ab}$ & $7.95 \pm 0.25 \mathrm{~b}$ & $2.95 \pm 0.09 \mathrm{~b}$ & $4.20 \pm 0.13 \mathrm{~b}$ & $-0.497 \pm 0.018 \mathrm{a}$ & $4.59 \pm 0.84 \mathrm{a}$ \\
PAR & $3.42 \pm 0.52 \mathrm{a}$ & $1027.76 \pm 0.64 \mathrm{~b}$ & $8.00 \pm 0.13 \mathrm{~b}$ & $2.97 \pm 0.05 \mathrm{~b}$ & $4.23 \pm 0.07 \mathrm{~b}$ & $-0.499 \pm 0.007 \mathrm{a}$ & $4.67 \pm 0.91 \mathrm{a}$ \\
TOT & $333 \pm 0.83 \mathrm{a}$ & $1027.01 \pm 0.92 \mathrm{a}$ & $7.78 \pm 0.28 \mathrm{a}$ & $2.89 \pm 0.10 \mathrm{a}$ & $4.11 \pm 0.14 \mathrm{a}$ & $-0.484 \pm 0.021 \mathrm{~b}$ & $5.90 \pm 1.33 \mathrm{~b}$ \\
Supplementation: & & & & & & \\
NO $3.49 \pm 0.84 \mathrm{a}$ & $1027.45 \pm 0.80 \mathrm{a}$ & $7.92 \pm 0.22 \mathrm{a}$ & $2.94 \pm 0.08 \mathrm{a}$ & $4.18 \pm 0.11 \mathrm{a}$ & $-0.494 \pm 0.017 \mathrm{a}$ & $4.80 \pm 1.08 \mathrm{a}$ \\
YES $3.44 \pm 0.47 \mathrm{a}$ & $1027.43 \pm 1.21 \mathrm{a}$ & $7.92 \pm 0.33 \mathrm{a}$ & $2.94 \pm 0.12 \mathrm{a}$ & $4.19 \pm 0.17 \mathrm{a}$ & $-0.494 \pm 0.021 \mathrm{a}$ & $5.50 \pm 1.23 \mathrm{~b}$ \\
Production system: & & & & & & \\
GR $3.52 \pm 0.79 \mathrm{a}$ & $1027.52 \pm 0.90 \mathrm{~b}$ & $7.95 \pm 0.23 \mathrm{~b}$ & $2.95 \pm 0.08 \mathrm{~b}$ & $4.20 \pm 0.12 \mathrm{~b}$ & $-0.496 \pm 0.016 \mathrm{a}$ & $4.93 \pm 1.08 \mathrm{a}$ \\
SES $3.14 \pm 0.55 \mathrm{a}$ & $1026.86 \pm 0.71 \mathrm{a}$ & $7.72 \pm 0.24 \mathrm{a}$ & $2.87 \pm 0.09 \mathrm{a}$ & $4.08 \pm 0.12 \mathrm{a}$ & $-0.479 \pm 0.019 \mathrm{~b}$ & $5.12 \pm 1.59 \mathrm{a}$ \\
\hline
\end{tabular}

$\mathrm{ZE}=$ Zebu. SZ= Swiss $\times$ Zebu, UD= Undefined breed, $\mathrm{HZ}=$ Holstein $\times$ Zebu. HAN $=$ Hand, MEC= Mechanic. NO= Not apply, $\mathrm{PAR}=$ Partial application, TOT $=$ Total application. $\mathrm{NO}=$ Not supplement, YES $=$ Supplement. GR= Grazing, SES $=$ Semi-stabled .

ab Values with different superscripts within the same column differ $(P<0.05)$.

La suplementación con alimento balanceado se practicó en el $20.5 \%$ de los casos. La eyección de la leche se promovió: sin usar oxitocina (47\%), con el uso parcial, sólo en vacas de difícil ordeño (30 \%) y aplicación a todo el hato lechero $(23 \%)$. El hato de ordeño fue de 34 vacas, con un rendimiento promedio de 4.95 L. vaca-1.

Los resultados del ANDEVA (Cuadros 2 y 3 ) mostraron que en las UP donde predominó la cruza Holstein x Cebú, se observó un mayor rendimiento con un menor contenido de GR y PR en la leche y valores elevados de CR $(P<0.05)$. El tipo de ordeño afectó $(P<0.05)$ los conteos bacterianos, ya que la leche obtenida mediante ordeño mecánico presentó conteos y AT inferiores a los obtenidos por ordeña manual. Además mediante el ordeño mecánico se observó un incremento aparente en el rendimiento, sin embargo, el ANDEVA a dos elevated values $(P<0.05)$. Type of milking affected $(P<0.05)$ bacterial counts, since the milk obtained by mechanical milking presented counts and TA lower than those by manual milking did. Furthermore, mechanical milking apparently increases the yield; however, the twoway ANOVA revealed that it relates more to a mix of factors, as supplementation and oxytocin application. Application of oxytocin in the entire herd increased $(P<0.05)$ the yield when compared to the partial or no use of, in relation with a low content of solids.

The PS based on grazing was related to elevated values of NFS, PR, LA, DE and lower values of $\mathrm{CR}$, when compared with the semi-stabled system. There were no differences $(P>0.05)$ in milk yield between both systems. Grazing-based system related to a higher bacterial load and TA $(P<0.05)$ to that seen in milk from semistabled systems 
Cuadro 3. Efecto de las prácticas de manejo sobre grupos indicadores de contaminación de la leche

Table 3. Effect of management practices on the spoilage indicators groups of milk

\begin{tabular}{|c|c|c|c|}
\hline & \multicolumn{3}{|c|}{ Variable } \\
\hline & Titratable acidity $(\mathrm{g} / \mathrm{L})$ & Log TBC (Log cfu/mL) & Log TCC (Log cfu/mL) \\
\hline \multicolumn{4}{|c|}{ Milking type: } \\
\hline $\mathrm{HA}$ & $1.34 \pm 0.12 b$ & $3.80 \pm 0.48 b$ & $2.55 \pm 0.52 b$ \\
\hline MEC & $0.87 \pm 0.23 a$ & $2.88 \pm 0.07 \mathrm{a}$ & $1.81 \pm 0.56 a$ \\
\hline \multicolumn{4}{|c|}{ Production system: } \\
\hline GR & $1.33 \pm 0.17 b$ & $3.83 \pm 0.49 b$ & $2.60 \pm 0.50 \mathrm{~b}$ \\
\hline SES & $1.19 \pm 0.07 \mathrm{a}$ & $3.11 \pm 0.23 \mathrm{a}$ & $1.85 \pm 0.34 \mathrm{a}$ \\
\hline
\end{tabular}

$\mathrm{TBC}=$ Total bacterial count; $\mathrm{TCC}=$ Total coliform count; $\mathrm{HA}=\mathrm{Hand}$; $\mathrm{MEC}=$ Mechanic. $\mathrm{GR}=$ Grazing. SES= Semi-stabled.

ab Values with different superscript within the same column differ $(P<0.05)$.

vías reveló que éste se relacionó más con una mezcla de factores, como la suplementación y aplicación de oxitocina. La aplicación de oxitocina en todo el hato incrementó $(\mathrm{P}<0.05)$ el rendimiento al compararse con el uso parcial o nulo, relacionándose con un contenido bajo de sólidos.

El SP basado en el pastoreo se relacionó con valores elevados de SNG, PR, LA, DE y valores inferiores de CR, al compararse con el sistema semi-estabulado. No se observaron diferencias $(P>0.05)$ en el rendimiento entre el sistema basado en el pastoreo y el semi-estabulado. El sistema basado en el pastoreo se relacionó con una carga bacteriana y AT superior $(P<0.05)$ a la observada en la leche proveniente de SP semi-estabulados.

Clasificación de calidad de las leches

Mediante el análisis cluster fue posible clasificar las muestras de leche en cinco grupos de calidad con base en las variables GR, SNG, CR, AT. En el dendrograma de la Figura 1 se pueden apreciar las UP asociadas a cada grupo. La distancia entre los grupos fluctuó entre 3 y 39. La distancia entre el grupo de leches de muy mala calidad con los grupos: de excelente calidad fue de 39; de buena calidad fue de 33; de deficiente calidad 24 y de mala calidad fue
Classification of milk quality

Cluster analysis allowed classifying milk samples in five groups of quality based on the variables FT, NFS, CR and TA. Dendrogram in Figure 1 shows association of PU with each group. The distance between the groups fluctuated between 3 and 39. The distance between the groups of milk from very poor quality with groups of excellent quality was 39; good quality was 33; poor quality 24 and very poor quality was 3 . According to the ANOVA, differences were observed $(P<0.05)$ among quality groups for the different variables (Figure 2 ). The so-called group of excellent quality, represented $14 \%$ of the sample and presented the highest values of FT $(43.60 \pm 2.49 \mathrm{~g} / \mathrm{L}), \mathrm{NFS}(83.34 \pm 1.11 \mathrm{~g} / \mathrm{L})$ and TA $(1.36 \mathrm{~g} / \mathrm{L})$ and the lowest in CR $(-0.520$ $\left.\pm 0.005{ }^{\circ} \mathrm{C}\right)$; this group met with the values set by the standard NOM-155-SCFI-2012 and FAO $(14,15)$. The good quality group accounted for $39 \%$ of the sample and presented values of FT $(32.57 \pm 2.80 \mathrm{~g} / \mathrm{L})$ and NFS (82.13 \pm $1.24 \mathrm{~g} / \mathrm{L}$ ) less than the excellent quality group, values of $C R\left(-0.512 \pm 0.010^{\circ} \mathrm{C}\right)$ superiors and TA $(1.39 \pm 0.14 \mathrm{~g} / \mathrm{L})$ similar to that group. This group met the minimum values set out in international and national standards, with the exception of the of NFS content which was below that required by the standard NOM-155-SCFI$2012^{(14)}$. Groups of poor (21\%), bad (3\%) and 
José Manuel Juárez-Barrientos, et al. / Rev Mex Cienc Pecu 2016;7(4):525-537

Figura 1. Dendrograma de muestras de leche por unidad de producción usando el método de ligamiento completo Figure 1. Dendrogram of milk samples by productive units using the complete linkage method

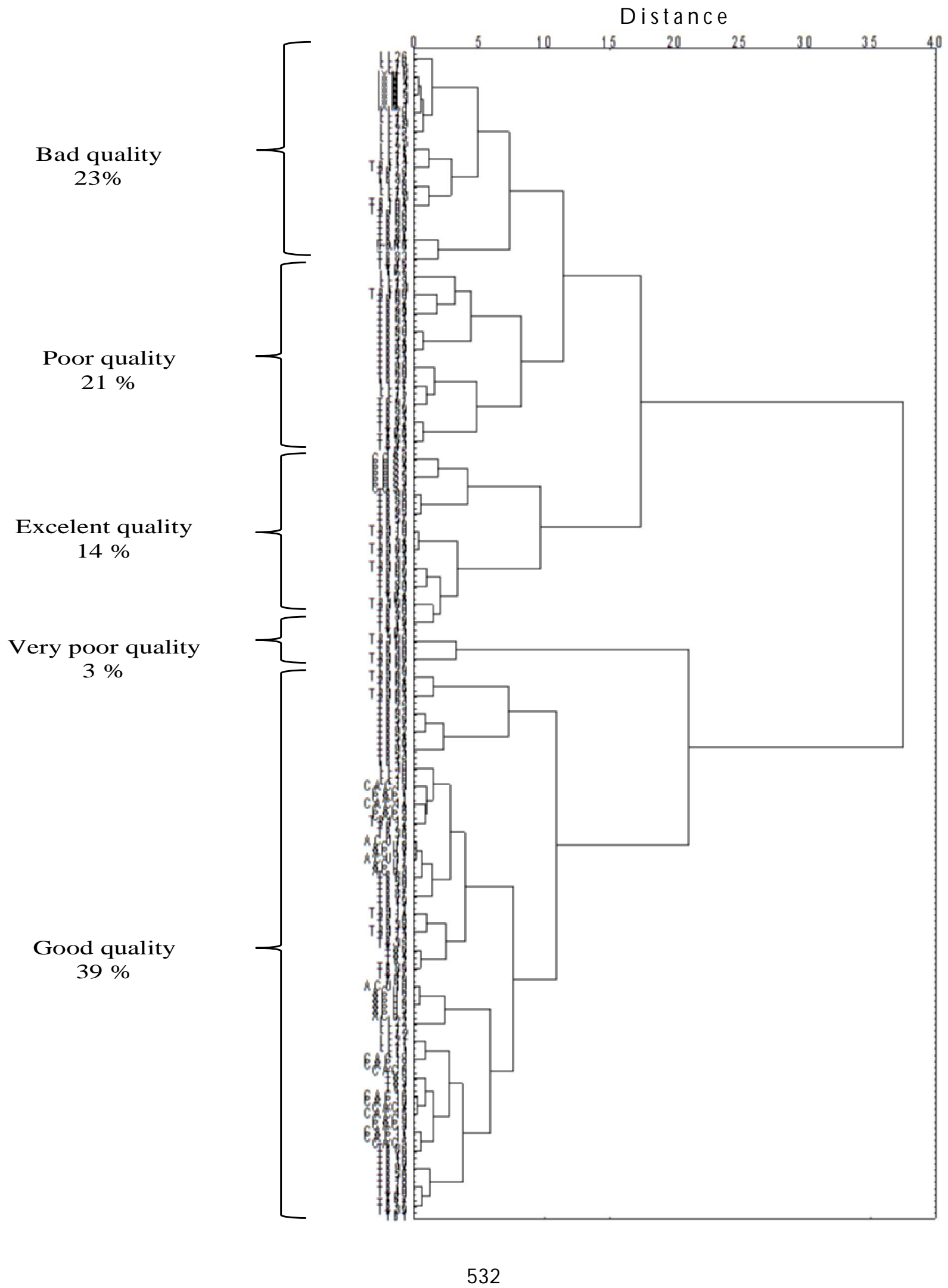


de 3. De acuerdo con el ANDEVA, se observaron diferencias $(P<0.05)$ entre los grupos de calidad para las diferentes variables (Figura 2). El grupo denominado de excelente calidad, representó el $14 \%$ de la muestra y presentó los valores más elevados de GR $(43.60 \pm 2.49 \mathrm{~g} / \mathrm{L})$, SNG $(83.34 \pm 1.11 \mathrm{~g} / \mathrm{L})$ y AT $(1.36 \mathrm{~g} / \mathrm{L})$ y los más bajos de CR $\left(-0.520 \pm 0.005^{\circ} \mathrm{C}\right)$. Este grupo cumplió con los valores establecidos por la norma NOM-155-SCFI-2012 y la FAO(14,15). El grupo denominado de buena calidad representó el $39 \%$ de la muestra y presentó valores de GR $(32.57 \pm 2.80 \mathrm{~g} / \mathrm{L})$ y SNG $(82.13 \pm 1.24 \mathrm{~g} / \mathrm{L})$ inferiores al grupo de excelente calidad, valores de CR $\left(-0.512 \pm 0.010{ }^{\circ} \mathrm{C}\right)$ superiores y AT $(1.39 \pm 0.14 \mathrm{~g} / \mathrm{L})$ similares a ese grupo. Este grupo cumplió con los valores mínimos establecidos en la norma internacional y very poor quality ( $23 \%$ ) showed similar values of NFS (between 77.20 and $77.80 \mathrm{~g} / \mathrm{L}$ ) below the established standards of reference and similar high values of CR (between -0.460 and $-0.480{ }^{\circ} \mathrm{C}$ ). They presented values below established standards for FT (between 15 and $10 \mathrm{~g} / \mathrm{L}$ ), except for the group of poor quality which presented high values of FT (42.80 \pm $5.30 \mathrm{~g} / \mathrm{L}$ ) similar to the values of the excellent quality group.

\section{DISCUSSION}

Physicochemical characteristics

The FT content was similar to the interval reported in tropical zones ( 32.6 to $34.5 \mathrm{~g} / \mathrm{L}$ )(16) and can be linked to the breed pattern Bos

Figura 2. Características de los grupos de leche formados con base en su calidad

Figure 2. Characteristics of groups formed based on milk quality
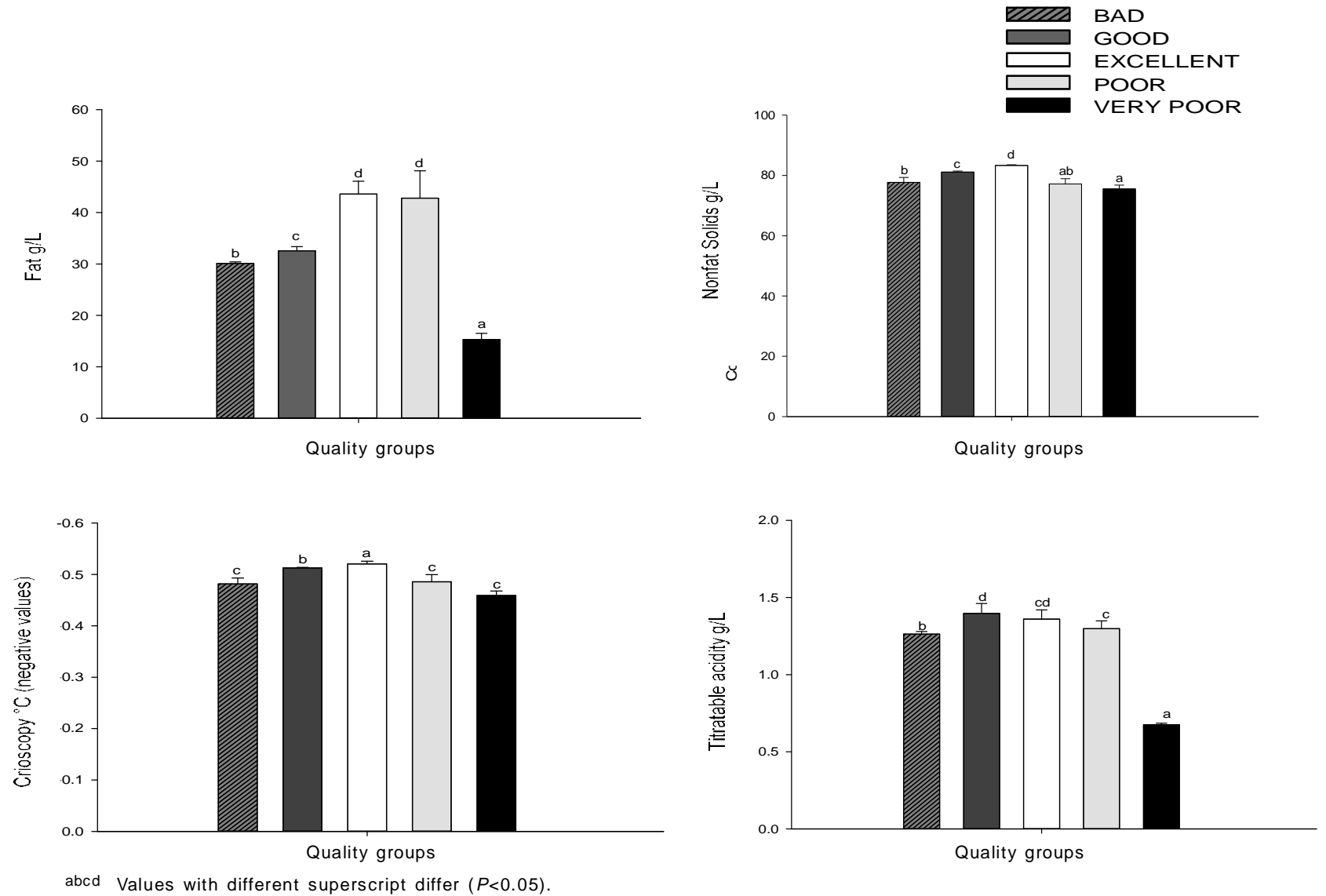
nacional, con excepción del contenido de SNG que estuvo por debajo de lo requerido por la norma NOM-155-SCFI-2012(14). Los grupos de deficiente $(21 \%)$, mala (3\%) y muy mala calidad $(23 \%)$ presentaron valores similares de SNG (entre 77.20 y $77.80 \mathrm{~g} / \mathrm{L}$ ) por debajo de lo establecido en las normas de referencia y valores elevados similares de CR (entre -0.460 y $-0.480{ }^{\circ} \mathrm{C}$ ). Presentaron además valores por debajo de lo establecido en las normas para GR (entre 15 y $10 \mathrm{~g} / \mathrm{L}$ ), a excepción del grupo de deficiente calidad que presentó los valores elevados de GR (42.80 $\pm 5.30 \mathrm{~g} / \mathrm{L})$ similares a los valores del grupo de excelente calidad.

\section{DISCUSIÓN}

Características fisicoquímicas

El contenido de GR fue similar al intervalo reportado en zonas tropicales (32.6 a $34.5 \mathrm{~g} /$ L) (16) y puede estar relacionado con el patrón racial Bos taurus $x$ Bos indicus(6). El contenido de PR, LA y SNG fue inferior al intervalo reportado en otros estudios $(16,17)$. Este contenido bajo de sólidos, a menudo se relaciona con un efecto de dilución(4) por el alto rendimiento causado por el componente B. taurus(7). Sin embargo, el contenido de sólidos encontrado en conjunto con los valores de CR superiores a $-0.530{ }^{\circ} \mathrm{C}$ y DE inferiores a $1028 \mathrm{~g} / \mathrm{L}$, revelan prácticas de adulteración por adición de agua(6), la cual tiene serias repercusiones en la industria transformadora y genera riesgos a la salud(18).

\section{Grupos indicadores de contaminación}

Los valores de CTB fueron similares a los observados en otro estudio y sugieren buenas prácticas higiénicas de ordeño(19). El $28 \%$ de las muestras fuera de norma en CCT reflejan fallas en el manejo post ordeño y en la eliminación de leche o agua residual de los depósitos. Los valores encontrados en los grupos indicadores de contaminación en la leche analizada garantizaron un proceso de pasteurización eficiente(13) pero no avala su inocuidad, por lo que el consumo de leche y taurus $x$ Bos indicus(6). The content of PR, LA and NFS was lower than the range reported in other studies $(16,17)$. This low solids content, often is related to a dilution effect (4) by the high-performance caused by the $\mathrm{B}$. Taurus component(7). However, the content of solids found in conjunction with the CR values superior to $-0.530{ }^{\circ} \mathrm{C}$ and $\mathrm{DE}$ below $1,028 \mathrm{~g} / \mathrm{L}$, reveal practices of adulteration by addition of water(6), which has serious implications for the processing industry and generates risks to health(18).

\section{Contamination indicators groups}

TBC values were similar to those observed in another study, which suggest good hygiene milking practices(19). Twenty eight (28) percent of samples out of the norm in TCC reflect failures in post milking management and lack of the elimination of milk or residual water from the tanks. The values found in the analyzed milk contamination indicators groups guaranteed an efficient pasteurization process(13), but it does not endorse their safety, so the consumption of milk and unpasteurized products represents a health risk for the possible presence of pathogenic bacteria(20).

Management practices and relationship with the characteristics of the milk

Yield increase related to the Holstein $x$ Zebu crossing has been reported previously(21) and in this study was also related with a low content of solids (Table 2), however, the CR and DE values are more related to adulteration practices than to physiological factors(22). Milk yield increased with the use of oxytocin. It has been observed previously, and is attributed to a greater alveolar contraction of the myoepithelial cells, moving the milk to the cavities available for ejection(23). The use of oxytocin increases milk production, but must take into account the low solids content which compromises its quality for being processed(24); a better option would be the supplementation of milking cows, which increases milk yield, from 4.80 to $5.50 \mathrm{~L} \cdot \mathrm{cow}^{-1}$, without affecting $(P>0.05)$ the solids content. 
derivados sin pasteurizar representa un riesgo para la salud por la posible presencia de bacterias patógenas(20).

Prácticas de manejo y relación con las características de la leche

El incremento en el rendimiento relacionado con la cruza Holstein x Cebú ha sido reportado con anterioridad(21) y en este estudio se relacionó además con un bajo contenido de sólidos (Cuadro 2), sin embargo, los valores de CR y $\mathrm{DE}$ se relacionan más con prácticas de adulteración que con factores fisiológicos(22). Se encontró un mayor rendimiento en la producción de leche con el uso de oxitocina; se ha observado anteriormente y se atribuye a una mayor contracción alveolar de las células mioepiteliales que causa que la leche se desplace a las cavidades de las cisternas disponibles para la eyección(23). El uso de oxitocina incrementa el rendimiento de la producción de leche, sin embargo se debe tomar en cuenta el bajo contenido de sólidos en la leche que compromete su calidad para ser procesada(24), siendo más viable la suplementación de vacas en ordeño, la cual incrementa el rendimiento; de 4.80 a $5.50 \mathrm{~L} \cdot$ vaca- $^{-1}$, sin afectar $(\mathrm{P}>0.05)$ el contenido de sólidos. El efecto del ordeño mecánico sobre el conteo bacteriano ha sido reportado(25), pero es necesario enfatizar que la limpieza del equipo de ordeño con detergentes es esencial para evitar los residuos de leche(4) que se relacionan con la contaminación por coliformes (26). Los conteos bacterianos elevados en SP de pastoreo se relacionó con la falta de salas de ordeño, ya que las vacas deben ordeñarse en corrales abiertos, lo que aumenta las posibilidades de contaminación ambiental(25).

Clasificación de calidad de las leches

Los grupos de excelente y buena calidad (53\% de la muestra) cumplieron con los valores requeridos por las normas de referencia, por lo que las acciones deben enfocarse en incrementar el nivel tecnológico implementado en las UP, lo cual se relaciona con la eficiencia y competitividad(27). El grupo de buena calidad
The effect of mechanical milking on the bacterial count has been reported(25), but it is necessary to emphasize that cleaning of the milking equipment with detergents is essential to avoid the milk residues $(4)$ that relate to contamination by coliforms (26). PS of grazing with high bacterial counts was related to the lack of milking parlous, since cows must be milked in open lots, which increases the chances of environmental contamination(25).

Classification of milk quality

Excellent and good quality groups (53\% of the sample) met the values required by reference standards, so actions should focus on increasing the level of technology implemented in the PU, which is related to efficiency and competitiveness (27). Good quality group failed to meet the minimum value of NFS in accordance with NOM-155-SCFI-2012. This problem could be related to small amounts of residual water(28) and can be solved through the training of operators in the milking and storage procedures.

The problematic groups named as poor, bad, and very poor quality ( $47 \%$ of the sample) presented low NFS and high CR values. The adequate actions for these groups should be to satisfy the demands of nutrients from the dairy herd, taking into account the variability in the availability of forage in tropical conditions(21) and that the nutritional aspect is a key component to improve production of dual purpose systems(29). Another important aspect is the awareness by the producers, that the intentional addition of water to the milk represents a fraud(18).

\section{CONCLUSIONS AND IMPLICATIONS}

The milk produced in the DDR 008 presented a low solids content, as $65 \%$ of samples did not meet the minimum value of protein, lactose and nonfat solids. The high cryoscopy and low density values indicate adulteration by addition of water. Contamination indicators groups show 
no cumplió con el valor mínimo de SNG establecido en la norma NOM-155-SCFI-2012. Este problema pudo relacionarse con pequeñas cantidades de agua residual(28) y puede resolverse mediante la capacitación de los operadores en los métodos de ordeño y almacenamiento. Los grupos problemáticos fueron los denominados de deficiente, mala y muy mala calidad (47\% de la muestra) que presentaron valores bajos de SNG y elevados de $C R$, por lo que deben aplicarse acciones correctivas enfocadas en satisfacer las demandas de nutrientes del hato lechero, tomando en cuenta que en condiciones tropicales existe variabilidad en la disponibilidad de forrajes(21) y que el aspecto nutricional es un componente clave para mejorar la producción en sistemas de doble propósito(29). Otro aspecto importante es la concientización por parte de los productores, de que la adición intencional de agua a la leche representa un fraude(18).

\section{CONCLUSIONES E IMPLICACIONES}

La leche producida en el DDR 008 presentó un bajo contenido de sólidos ya que el $65 \%$ de las muestras no cumplieron con el valor mínimo de proteína, lactosa y sólidos no grasos. Los valores elevados de crioscopía y bajos de densidad indican una adulteración por adición de agua. Los grupos indicadores de contaminación muestran que el $28 \%$ de las muestras presentaron valores elevador de CCT $\left(5.80 \times 10^{2}\right)$, lo que indica que mediante el proceso de pasteurización será posible obtener una leche de buena calidad microbiológica con valores dentro de las normas de referencia. La información demostró que existe relación entre la suplementación, el rendimiento y las características fisicoquímicas de la leche, siendo posible incrementar el rendimiento hasta un $20 \%$ sin afectar el contenido de sólidos. Fue posible identificar los grupos y las UP que los conforman y que requieren acciones de intervención para mejorar la calidad de la leche. A través de esta metodología se espera que las intervenciones por parte de las instancias gubernamentales y privadas se planteen con that $28 \%$ of the samples presented high CCT values $\left(5.80 \times 10^{2}\right)$, which indicates that, through the process of pasteurization, it will be possible to obtain a good quality milk with microbiological values within the reference norms. The information showed that there is a relationship between supplementation, yield and physico-chemical characteristics of milk, being possible to increase performance up to $20 \%$ without affecting the content of solids. It was possible to identify groups and the PU to shape them and requiring intervention actions to improve the milk quality. Through this methodology, it expects that interventions by governmental and private institutions arise based on reality to avoid resources waste.

End of english version

base en la realidad y se evite el dispendio de recursos.

\section{LITERATURA CITADA}

1. Monforte JM, Arjona GR, González JM. Los sistemas de doble propósito y los desafíos en los climas tropicales de México. Arch Latinoam Prod Anim 2006; 14(3): 105-114.

2. Vilaboa-Arroniz J, Díaz-Rivera P, Ruiz-Rosado O, PlatasRosado DE, González-Muñoz S, Juárez-Lagunes F. Caracterización socioeconómica y tecnológica de los agroecosistemas con bovinos de doble propósito de la región del Papaloapan, Veracruz, México. Trop Subtrop Agroecosyst 2009; 10(1):53-62.

3. Romo BCE, Valdivia FAG, Carranza TRG, Cámara CJ, Zavala $A M P$, Flores $A E$, Espinosa GJA. Brechas de rentabilidad económica en pequeñas unidades de producción de leche en el altiplano central mexicano. Rev Mex Cienc Pecu 2014; 5(3):273-290.

4. Sraïri MT, Benhouda H, Kuper M, Le GPY. Effect of cattle management practices on raw milk quality on farms operating in a two-stage dairy chain. Trop Anim Health Prod 2009; 41(2): 259-272.

5. Red Comunitaria Vasconcelos. Manual por regiones: Distrito de Desarrollo Rural 08 Cd. Alemán. Departamento de Gestión Educativa. Xalapa, Veracruz, México. 2009.

6. Calderón A, García F, Martínez G. Indicadores de calidad de leches crudas en diferentes regiones de Colombia. Rev MVZ Córdoba 2006;11(1):725-737. 
7. De Marchi M, Bittante G, Dal ZR, Dalvit C, Cassandro M. Effect of Holstein Friesian and Brown Swiss breeds on quality of milk and cheese. J Dairy Sci 2008;91(10):4092-4102.

8. Álvarez-Fuentes G, Herrera-Haro JG, Alonso-Bastida G, Barreras-Serrano A. Calidad de la leche cruda en unidades de producción familiar del sur de Ciudad de México. Arch Med Vet 2012;44(3):237-242.

9. Pappas CS, Tarantilis PA, Moschopoulou E, Moatsou G, Kandarakis I, Polissiou MG. Identification and differentiation of goat and sheep milk based on diffuse reflectance infrared Fourier transform spectroscopy (DRIFTS) using cluster analysis. Food Chem 2008; 106(3):1271-1277.

10. INEGI : Instituto Nacional de Estadística y Geografía. Cría y explotación de animales en Veracruz de Ignacio de la Llave. Censo Agropecuario 2007. México 2013.

11. Secretaría de Salud. NOM-109-SSA1-1994, Bienes y Servicios. Procedimiento para la toma, manejo y transporte de muestras de alimentos para su análisis microbiológico. México 2014.

12. AOAC. Official methods of analysis. 17th ed. Arlington, VA, USA: Association of Official Analytical Chemists. 2005.

13. Pantoja J CF, Reinemann DJ, Ruegg PL. Associations among milk quality indicators in raw bulk milk. J Dairy Sci 2009; 92(10): 4978-4987.

14. Secretaría de Economía. NOM-155-SCFI-2012. Leche, formula láctea y producto lácteo combinado, especificaciones fisicoquímicas, información comercial y métodos de prueba. México. 2011.

15. Draaiyer J, Dugdill B, Bennett A, Mounsey J. Milk testing and payment systems. In: Food and Agriculture Organization of the United Nations (FAO) editor. A practical guide to assist milk producer groups. Roma, Italia: FAO; 2009:1356. http://www.fao.org/docrep/012/i0980e/i0980e00.htm. Accessed Dic 13, 2014.

16. Bernal ML, Rojas GM, Vázquez FC, Espinoza OA, Estrada FJ , Castelán OO. Determinación de la calidad fisicoquímica de la leche cruda producida en sistemas campesinos en dos regiones del Estado de México. Vet Méx 2007;38(4):395407.

17. Briñez WJ, Valbuena E, Castro G, Tovar A, Ruiz-Ramírez J. Algunos parámetros de composición y calidad en leche Cruda de vacas doble propósito en el municipio Machiques de Perijá Estado Zulia, Venezuela. Rev Cient-Fac Cien V 2008; 18(5):607-617.
18. Das S, Sivaramakrishna M, Biswas K, Goswami B. Performance study of a constant phase angle based impedance sensor to detect milk adulteration. Sensor Actuat A-Phys 2011;167(2):273-278.

19. D'amico DJ, Donnelly CW. Microbiological quality of raw milk used for small-scale artisan cheese production in Vermont: effect of farm characteristics and practices. J Dairy Sci 2010; 93(1):134-147.

20. Claeys WL, Cardoen S, Daube G, De Block J, Dewettinck K, Dierick K, et al. Raw or heated cow milk consumption: Review of risks and benefits. Food Control 2013;31(1):251-262.

21. Osorio MM, Segura JC. Environmental and breed effects on test day milk yields of dual-purpose crossbred cows under tropical conditions of Mexico. J Appl Anim Res 2004; 25(2): 125-128.

22. Neville CM, Jensen RG. The physical properties of human and bovine milks. In: Jensen RG editor. Handbook of milk composition. San Diego, USA: Academic Press; 1995:82-85.

23. Bruckmaier RM, Macuhova J, Meyer HHD. Specific aspects of milk ejection in robotic milking: a review. Lives Prod Sci 2001; 72(1): 169-176.

24. Glantz $M$, Lindmark $M, H$, Stålhammar $H$, Bårström LO, Fröjelin $M$, Knutsson A, Teluk C, Paulsson M. Effects of animal selection on milk composition and processability. J Dairy Sci 2009;92(9):4589-4603.

25. Mhone TA, Matope G, Saidi PT. Aerobic bacterial, coliform, Escherichia coli and Staphylococcus aureus counts of raw and processed milk from selected smallholder dairy farms of Zimbabwe. Int J Food Microbiol 2011;151(2):223-228.

26. Pantoja JCF, Reinemann DJ, Ruegg PL. Factors associated with coliform count in unpasteurized bulk milk. J Dairy Sci 2011;94(6): 2680-2691.

27. Atzori AS, Tedeschi LO, Cannas A. A multivariate and stochastic approach to identify key variables to rank dairy farms on profitability. J Dairy Sci 2013;96(5):3378-3387.

28. Sánchez A, Sierra D, Luengo C, Corrales JC, De La Fe C, Morales CT, Gonzalo C. Evaluation of the MilkoScan FT 6000 milk analyzer for determining the freezing point of goat's milk under different analytical conditions. J Dairy Sci 2007; 90(7):3153-3161.

29. Reynoso-Campos O, Fox DG, Blake RW, Barry MC, Tedeschi LO, Nicholson CF, Oltenacu PA. Predicting nutritional requirements and lactation performance of dual-purpose cows using a dynamic model. Agr Syst 2004;80(1):67-83. 
538 